\title{
PENGEMBANGAN PERMAINAN MAZE TIGA DIMENSI PADA PEMBELAJARAN FISIK MOTORIK ANAK KELOMPOK B
}

\author{
Oleh: Arwendis Wijayanti \\ (Dosen STKIP Modern Ngawi) \\ Email: arwendis.wijayanti@ gmail.com
}

\begin{abstract}
Abstrak
Penelitian ini dilaksanakan dengan tujuan untuk mengembangkan permainan Maze Tiga Dimensi yang aman, mudah dan menyenangkan dilakukan di RA Perwanida I Jogorogo untuk mengembangkan kemampuan fisik motorik anak usia kelompok $B$ dan aspek perkembangan yang lainnya. Model pengembangan yang digunakan dalam penelitian ini adalah model pengembangan Borg and Gall. Prosedur permainan Maze Tiga Dimensi pada pembelajaran fisik motorik adalah 1) Melakukan penelitian dan pengumpulan informasi, 2) melakukan perencanaan, selanjutnya dievaluasi oleh para ahli, 3) mengembangkan bentuk produk awal permainan Maze Tiga Dimensi, 4) melakukan uji coba kelompok kecil dengan 8 subjek, 5) melakukan revisi terhadap uji coba kelompok kecil (6)melakukan uji coba kelompok besar dengan 40 subjek, 7) melakukan revisi produk. Instrumen yang digunakan berupa kuisoner berisi tentang rancangan produk dan produk yang telah dibuat. Teknik analisis data yang digunakan adalah analisis kualitatif dan kuantitatif berupa presentase. Kesimpulan penelitian dan pengembangan produk permainan Maze Tiga Dimensi untuk pembelajaran fisik motorik adalah memberikan wawasan dan pengetahuan baru tentang pembelajaran fisik motorik, memperdalam pengembangan permainan Maze Tiga Dimensi, disarankan agar mengembangkan lebih luas lagi misalnya penambahan aspek perkembangan fisik motorik lain dalam permainan Maze Tiga Dimensi, dapat diterapkan kembali dengan menambahkan variasi kesulitan pada permainan.
\end{abstract}

Kata kunci: Pengembangan, Permainan Maze Tiga Dimensi, Fisik Motorik

\section{DEVELOPMENT OF THREE-DIMENSIONAL MAZE GAME FOR LEARNING THE PHYSICAL MOTORIC OF GROUP B}

\begin{abstract}
This research was carried out with the aim to develop a three-dimensional Maze game that is safe, easy and fun done in RA Perwanida I Jogorogo to develop physical abilities of the motor age groups $B$ and other developmental aspects. The development Model used in this study is a model of development of the Borg and Gall. Three dimensional Maze game procedures on learning the physical motor is (1) conducting research and gathering information, (2) conducts planning, further evaluated by experts, (3) developed a form of early product of three-dimensional Maze game, (4) Doing a test run in small groups with 8 subject, (5) Do a revision of trials for small groups (6) perform a test run
\end{abstract}


with a group of 40 subjects, 7) do a revision of the product. The Instrument used was a kuisoner is about the design of the product and the product that has been made. Data analysis technique used is qualitative and quantitative analysis in the form of a percentage. Conclusions of research and product development of threedimensional Maze game for learning the physical motor is giving new insights and knowledge about physical motor skills learning, deepen a three-dimensional maze game development recommended that developed more broadly, for example the addition of other aspects of physical development motor in a threedimensional maze game, can be applied again by adding variations to the difficulty of the game.

Keyword: Development, Three Dimensional Maze Game, Physical-Motoric

\section{A. PENDAhULUAN}

Pendidikan mengemban tugas untuk dapat mengembangkan seluruh aspek perkembangan yang dimiliki setiap anak. Anak usia 4-6 tahun merupakan bagian dari anak usia dini atau disebut sebagai anak usia prasekolah. Pada usia tersebut anak perlu mendapat bimbingan yang tepat, sehingga memungkinkan anak untuk dapat mengembangkan semua aspek secara optimal. Peran guru/ pendidik maupun orang tua sangat diperlukan dalam upaya menumbuhkan dan mengembangkan potensi anak. Dalam mengembangkan seluruh perkembangan anak tidah hanya dapat dilakukan hanya dengan duduk di bangku dan mengerjakan lembar kerja siswa saja, namun hal tersebut dapat dilakukan dalam kegiatan pembelajaran, yang sesuai dengan kebutuhan dan karakteristik anak. Kegiatan pembelajaran yang sesuai dengan anak melalui bermain.

Bermain sangat penting bagi anak untuk mengembangkan jasmani dan rohani anak. Salah satu dan utama manfaat dari bermain adalah untuk mengembangkan kemampuan fisik dan motorik anak. Perkembangan motorik menurut Hurlock (1978:150) berarti perkembangan pengendalian gerakan jasmaniah melalui kegiatan pusat syaraf, urat syaraf, dan otot yang terkoordinasi. Bermain adalah suatu aktivitas yang langsung, spontan dimana seorang anak berinteraksi dengan orang lain dan atau dengan benda-benda di sekitarnya, dilakukan dengan senang (gembira), atas inisiatif sendiri, menggunakan daya khayal (imajinatif), menggunakan sebanyak mungkin alat inderanya dan seluruh anggota tubuhnya (Sutama dan Budhojo, 2012:57). 
Wahana Didaktika Vol. 16 No.3 September 2018 : 276-283

Melalui bermain anak dapat memiliki kemampuan untuk mengeksplorasi, menemukan, mengekspresikan sesuatu yang menarik dan menyenangkan bagi dirinya, serta anak dapat memahami interaksi antara dirinya dan lingkungan sosialnya, belajar bergaul dan memahami aturan yang ada. Oleh karena itu, guru pra sekolah (TK) harus mampu mengembangkan suatu permainan yang dapat memfasilitasi pertumbuhan dan perkembangan anak. Perkembangan kemampuan fisik motirik anak dapat dikembangkan melalui permainan Maze Tiga Dimensi. Permainan Maze Tiga Dimensi merupakan perubahan sebuah aktivitas permainan mencari jejak yang semula dari Lembar Kerja Siswa (LKS) berbentuk 2 dimensi kemudian dirubah ke bentuk yang nyata (3 dimensi) dan dilakukan di luar kelas serta dirancang berkelanjutan dari aktivitas satu ke aktivitas yang lain dengan menggunakan alat-alat permainan yang aman, menarik dan menyenangkan bagi anak.

Berdasarkan hasil pengamatan dan wawancara yang dilakukan kepada dua orang guru kelas di RA Perwanida I Jogorogo, khususnya pada pembelajaran fisik motorik diperoleh permasalahan sebagai berikut: anak masih kurang mampu dalam hal menangkap bola pada kegiatan melempar dan menangkap bola ke atas, dalam kegiatan senam anak masih terlihat kurang antusias, terlihat bosan dikarenakan kegiatan yang dilakukan berulang-ulang dan hanya itu-itu saja. Selain itu, pada kegiatan fisik motorik lainnya seperti berjalan di atas papan titian , ada beberapa anak yang tidak mau melakukan dikarenakan kurangnya kepercayaan diri pada anak. Kemungkinan hal ini disebabkan kurang berkembangnya keterampilan motorik, koordinasi gerak tangan dan kaki anak.

Berdasarkan permasalahan di atas, perlu adanya pengembangan keterampilan fisik motorik yang efektif, menarik dan menyenangkan, yang dapat dilakukan di luar kelas. Selain itu, pembelajaran fisik motorik yang optimal juga harus dapat memperhatikan komponen-komponen perkembangan fisik motorik. Pembelajaran yang dapat dikembangkan di Taman Kanak-kanak dan dapat membuat anak senang dan mudah melakukannya serta aman bagi anak adalah pembelajaran fisik motorik berupa permainan yang akan dilakukan di RA Perwanida I Jogorogo. 
Pengembangan Permainan Maze...(Arwendis Wijayanti)

Tujuan penelitian adalah dengan adanya Permainan Maze Tiga Dimensi diharapkan dapat menjadi alternatif dalam mengembangkan kegiatan pembelajaran fisik motorik yang mudah, aman, menyenangkan bagi anak, membuat anak menjadi aktif dalam melakukan kegiatan pembelajaran fisik motorik serta mengembangkan seluruh aspek perkembangan anak Kelompok B di RA Perwanida I Jogorogo.

\section{B. METODOLOGI PENELITIAN}

Dalam melaksanakan pengembangan pembelajaran fisik motorik melalui permainan Maze Tiga Dimensi ini, peneliti menggunakan pedoman model pengembangan (research and development) Borg dan Gall (1983). Oleh karena penelitian ini dilaksanakan pada 1 sekolah, maka pada penelitian ini ditetapkan adanya 7 langkah, sebagai berikut: (1) Melakukan penelitian dan pengumpulan informasi (kajian pustaka, pengamatan kelas, persiapan laporan pokok persoalan). (2) Menyusun perencanaan berupa penyusunan rancangan produk permainan Maze Tiga Dimensi (penyusunan aktivitas fisik motorik, perumusan tujuan dan penentuan urutan pembelajaran), dan untuk dievaluasi ahli. (3) Mengembangkan bentuk produk awal berupa "Permainan Maze Tiga Dimensi" untuk dievaluasi oleh ahli pembelajaran anak usia dini, ahli media pembelajaran anak usia dini dan ahli fisik motorik. (4) Melakukan uji coba lapangan permulaan/uji kelompok kecil terhadap 8 anak kelompok B di RA Perwanida I Jogorogo. (5) Merevisi produk awal berdasarkan hasil uji coba lapangan permulaan/uji kelompok kecil untuk melakukan uji lapangan utama sesuai dengan saran-saran hasil uji lapangan permulaan. (6) Melakukan uji lapangan utama di RA Perwanida I Jogorogo dengan jumlah anak 40 anak. (7) Merevisi produk berdasarkan saran-saran hasil uji lapangan utama.

\section{HASIL PENELITIAN DAN PEMBAHASAN}

Berdasarkan pengumpulan data dari kajian uji coba Pengembangan Permainan Maze Tiga Dimensi Pada Pembelajaran Fisik Motorik Anak Kelompok B di RA Perwanida I Jogorogo di bawah ini: 
Wahana Didaktika Vol. 16 No.3 September 2018 : 276-283

1. Berdasarkan dari tinjauan para ahli, maka rancangan produk keseluruhan permainan yang dibuat, direvisi dan dikonsultasikan pada ahli fisik motorik anak usia dini dan ahli pembelajaran pendidikan anak usia dini, dan ahli media pembelajaran anak usia dini, yang kemudian digunakan sebagai dasar untuk memperbaiki kualitas produk pengembangan, sebelum memasuki tahap uji coba kelompok kecil.

2. Hasil analisis data uji coba kelompok kecil terhadap 8 anak kelompok B di RA Perwanida I Jogorogo diperoleh penilaian sebanyak 95\% anak mudah melakukan kegiatan permainan Maze Tiga Dimensi, 100\% anak merasa aman melakukan kegiatan permainan Maze Tiga Dimensi, 100\% anak merasa senang melakukan kegiatan permainan Maze Tiga Dimensi, serta dalam aspek fisik motorik diperoleh $96,87 \%$ anak dapat melakukan semua kegiatan pada permainan Maze Tiga Dimensi dengan baik dan benar.

3. Hasil analisis data uji coba kelompok besar terhadap 37 anak kelompok B di RA Perwanida I Jogorogo diperoleh penilaian sebanyak 99,45\% anak mudah melakukan kegiatan permainan Maze Tiga Dimensi, 99,45\% anak merasa aman melakukan kegiatan permainan Maze Tiga Dimensi, 100\% anak merasa senang melakukan kegiatan permainan Maze Tiga Dimensi, serta dalam aspek fisik motorik diperoleh $88,64 \%$ anak dapat melakukan semua kegiatan pada permainan Maze Tiga Dimensi dengan baik dan benar.

Tujuan dari permainan ini adalah mengembangkan motorik kasar anak dalam rangka melatih kekuatan, kelentukan, keseimbangan, kelincahan, koordinasi dan ketepatan pada saat melewati di setiap pos. Permainan ini juga dapat melatih daya konsentrasi dan kognitif anak yang mana anak dapat berfikir untuk menemukan jalan yang benar dengan mengikuti jejak-jejak kaki yang benar serta bahasa, sosial emosional dan moral, yang mana dengan berinteraksi dengan teman maupun guru, anak mau dapat mengendalikan emosi dengan mau menunggu giliran bermain dan menaati peraturan yang ada.

Aspek-aspek perkembangan fisik motorik yang terkait dengan unsur-unsur kebugaran jasmani adalah melatih ketepatan, keseimbangan, kelentukan, 
kekuatan, kelincahan dan koordianasi tubuh anak. Sehingga juga dapat berguna dalam mengembangkan kemampuan fisik motorik pada masa yang akan datang.

Dalam permainan ini, anak harus melewati beberapa rintangan yang tersedia dengan cara mengikuti dan mencari jejak kaki yang tepat sesuai dengan peraturan permainan sehingga anak dapat sampai ke garis akhir permainan. Adapun langkah-langkah permainan yang dilakukan anak yaitu:

1) Anak menuju Pos I dengan berjalan menulusuri jejak-jeka kaki dan mencari jejak kaki yang berukuran lebih besar dan mencari gambar tersenyum untuk menentukan mengambil bendera dengan gambar apa. Dilanjutkan dengan membawa bendera dan berjalan menuju Pos II.

2) Pada Pos II anak berjalan di atas papan titian dengan tangan dibentangkan ke samping sambil membawa bendera, kemudian bendera dimasukkan ke dalam botol yang telah disediakan sesuai dengan gambar dan warna bendera. Selain itu, anak diminta untuk mengingat gambar apa yang telah diperoleh saat itu sampai aktivitas terakhir.

3) Setelah melalui Pos II anak berjalan menulusuri jejak kaki menuju Pos III.

4) Pada Pos III anak berdiri di sebuah alas kaki, kemudian anak membungkuk untuk memindahkan sebuah halangan yang berupa kepingan geometri ke kanan dan ke kiri.

5) Setelah itu berlari menuju Pos IV.

6) Di Pos IV ini anak terus berlari dengan melompati dua rintangan dari kardus.

7) Setelah selesai melalui Pos IV anak berjalan kembali melalui jejak kaki menuju Rute terakhir atau Pos V.

8) Pada Pos V anak mengambil bola sesuai dengan warna pada gambar benda yang ada di rute 2 kemudian berlari zig-zag menuju botol untuk meletakkan bola.

Hasil uji coba lapangan (kelompok besar) menunjukkan bahwa pembelajaran fisik motorik melalui permainan Maze Tiga Dimensi berpengaruh cukup besar bagi perkembangan fisik motorik anak. Sebagian besar anak merasa senang melakukannya, karena dilakukan dengan melalui kegiatan permainan dan perasaan senang maka semua aktivitas fisik motorik yang nampak sulit bagi anak 
Wahana Didaktika Vol. 16 No.3 September 2018 : 276-283

ternyata mudah untuk dilakukan. Berdasarkan hasil dari analisis data uji lapangan (kelompok besar) tersebut dapat disimpulkan bahwa produk ini dapat digunakan sebagai salah satu alternatif pembelajaran yang menarik bagi anak, dapat membuat anak aktif, kreatif dan senang dalam kegiatan pembelajaran fisik motorik di RA Perwanida I Jogorogo.

Berdasarkan hasil observasi terhadap anak selama melakukan penelitian dan pengembangan produk permainan Maze Tiga Dimensi, diperoleh temuantemuan yaitu: (1) kemampuan fisik motorik anak meliputi: ketepatan, keseimbangan, kelentukan, kekuatan dan kelincahan; (2) kemampuan sosialemosional anak meliputi: anak mampu mengendalikan emosi ketika harus antri (menunggu giliran) untuk bermain. (3) kemampuan kognitif anak meliputi: anak dapat membedakan posisi kanan dan kiri serta daya ingat anak terasah; (4) kemampuan nilai moral anak meliputi: anak mampu mematuhi peraturan dalam permainan; (5) kemampuan bahasa anak meliputi: anak mampu berinteraksi dengan teman, guru ketika menanyakan hal yang kurang dimengertinya tentang kegiatan permainan tersebut. Berdasarkan temuan- temuan tersebut, maka produk permainan Maze Tiga Dimensi selain dapat mengembangkan kemampuan fisik motorik, juga dapat mengembangkan kemampuan sosial emosional, kognitif, moral dan bahasa anak.

\section{SIMPULAN}

Berdasarkan hasil uji coba lapangan yang telah dilakukan di RA Perwanida I Jogorogo tentang pengembangan permainan Maze Tiga Dimensi pada pembelajaran fisik motorik anak kelompok B, maka dapat disimpulkan bahwa:

1. Penerapan Permainan Maze Tiga Dimensi untuk mengembangkan pembelajaran fisik motorik anak di Kelompok B RA Perwanida I Jogorogo dilaksanakan di luar kelas. Dalam uji coba lapangan ini diikuti oleh 37 anak. Setelah guru mempersiapkan lapangan permainan, guru memberikan penjelasan sederhana tentang permainan Maze Tiga Dimensi ini. Anak melakukan permainan ini secara bergantian. Dari 37 anak, 36 anak dapat melakukannya dengan mudah dan aman serta 37 anak merasa senang 
melakukan permainan Maze Tiga Dimensi ini. Dalam permainan ini memiliki tujuan untuk melatih ketepatan, keseimbangan, kelentukan, kekuatan, kelincahan dan koordinasi tubuh anak serta mengembangkan seluruh aspek perkembangan anak khususnya perkembangan fisik motorik.

2. Berdasarkan hasul uji coba lapangan (uji coba kelompok besar) dapat dilihat bahwa permainan Maze Tiga Dimensi mudah, aman dan menyenangkan bagi anak. Hal ini dapat dilihat dari perolehan data 99,45\% anak mudah melakukan permainan Maze Tiga Dimensi, 99,45\% anak merasa aman saat melakukan permainan Maze Tiga Dimensi, dan 100\% anak senang saat melakukan permainan Maze Tiga Dimensi.

\section{DAFTAR PUSTAKA}

Borg, W.R \& Gall, M.D. (1983). Educational Research and Introduction. London: Longman.

Hurlock, Elizabeth. B. (1978). Perkembangan Anak. Jakarta: Erlangga.

Sutama, I Wayan. \& Budhojo, Kentar. (2012). Modul Pengembangan Materi Umum Model pembelajaran PAUD. Malang: Kementerian Pendidikan dan Kebudayaan Universitas Negeri Malang. 